\title{
Bathing Activities and Microbiological River Water Quality in the Paris Area: A Long-Term Perspective
}

\author{
Jean-Marie Mouchel, Françoise S. Lucas, Laurent Moulin, \\ Sébastien Wurtzer, Agathe Euzen, Jean-Paul Haghe, Vincent Rocher, \\ Sam Azimi, and Pierre Servais
}

\section{Contents}

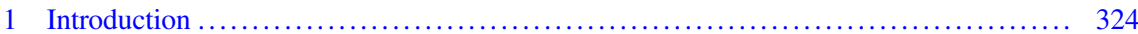

2 Bathing in the Seine and Marne Rivers in Paris and Its Suburbs Has Recently Become

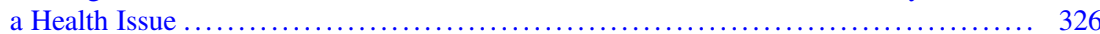

2.1 Bathing in Paris: Washing and Cooling Off .......................... 326

2.2 Bathing Despite Regulations and the Development of Industry and Harbors ..... 327

2.3 Bathing in Suburban Areas: From the Middle of the Nineteenth Century ........ 327

2.4 A Social Control More Than a Matter of Public Sanitation .................... 329

3 The Concept of Fecal Indicator Bacteria ................................ 329

The copyright year of the original version of this chapter was corrected from 2019 to 2020 . A correction to this chapter can be found at https://doi.org/10.1007/698_2020_667

J.-M. Mouchel $(\bowtie)$

Sorbonne Université, CNRS, EPHE, UMR Metis, Paris, France

e-mail: jean-marie.mouchel@sorbonne-universite.fr

F. S. Lucas

Faculté des Sciences et Technologie, Université Paris Est-Créteil, LEESU UMR-MA 102, Créteil Cedex, France

L. Moulin and S. Wurtzer

R\&D Department, Eau de Paris, Ivry sur Seine, France

\author{
A. Euzen \\ Université Paris Est, Ecole des Ponts ParisTech, CNRS, UMR LATTS, Marne-la-Vallée, France \\ J.-P. Haghe \\ Université Paris-1, UMR 8586 PRODIG, Paris, France \\ V. Rocher and S. Azimi \\ R\&D Department, SIAAP, Colombes, France \\ P. Servais \\ Ecology of Aquatic Systems, Université Libre de Bruxelles, Brussels, Belgium
}


4 Long-Term Fluctuations of Microbiological Water Quality in the Seine and Marne Rivers ........................................................... 331

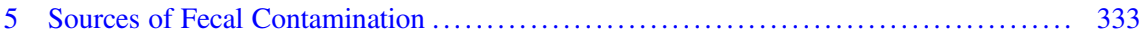

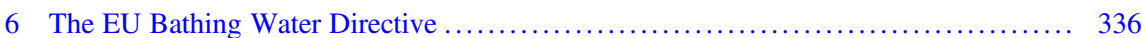

7 Present Level of Fecal Bacteria Indicators in the Seine and Marne Rivers in the Paris Area ..................................................... 339

7.1 The Main Factors Explaining the Distribution of E. coli ................... 339

7.2 Longitudinal Distributions of E. coli in the Urban Sections of the Seine and Marne

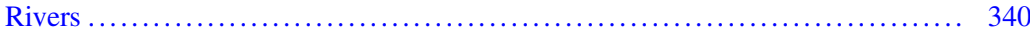

8 Presence of Pathogens in the Seine and Marne Rivers in the Paris Area .............. 343

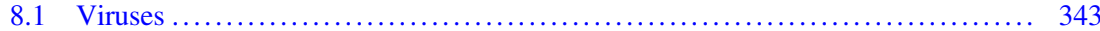

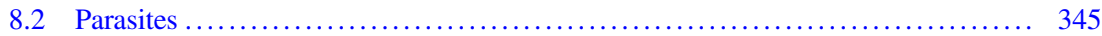

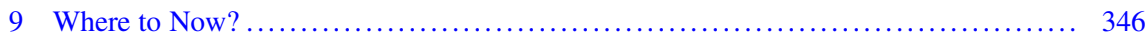

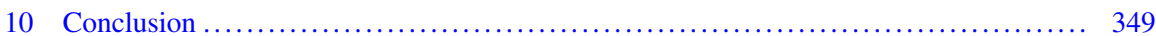

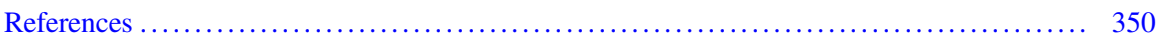

\begin{abstract}
This chapter presents the historical aspects regarding swimming in rivers in the Paris region since the seventeenth century, including the concept of fecal contamination indicator bacteria (FIBs) developed at the very beginning of the twentieth century, and historical contamination data covering more than one century in the Paris agglomeration. The sources of microbiological contamination of river waters are quantified, showing the importance of rain events. The present contamination levels are presented with reference to the European Directive for bathing water quality. FIB levels show that the sufficient quality for bathing is not reached yet in any of the monitored stations. A comprehensive data set regarding waterborne pathogens (viruses, Giardia, Cryptosporidium) in the Seine and Marne rivers is presented as a necessary complement to the regulatory FIB data to better evaluate health risks. The last section concludes on the actions to be conducted to improve the rivers' microbiological quality in the coming years.
\end{abstract}

Keywords Bathing, Fecal indicator bacteria, LTSER “Zone Atelier Seine”, Microbiology, Paris agglomeration, Pathogens, PIREN-Seine, Seine River

\title{
1 Introduction
}

Bathing activities have been observed for a very long time in the main rivers of the Paris region (Fig. 1). They were progressively banned during the twentieth century mainly because of the significant degradation of water quality, most particularly microbiological quality of surface waters, which presents a major health challenge. Contaminated water can contain various types of pathogenic microorganisms (bacteria, viruses, parasitic protozoa) likely to cause various types of infections (gastrointestinal, respiratory, ocular, cutaneous) in humans. The main source of these 


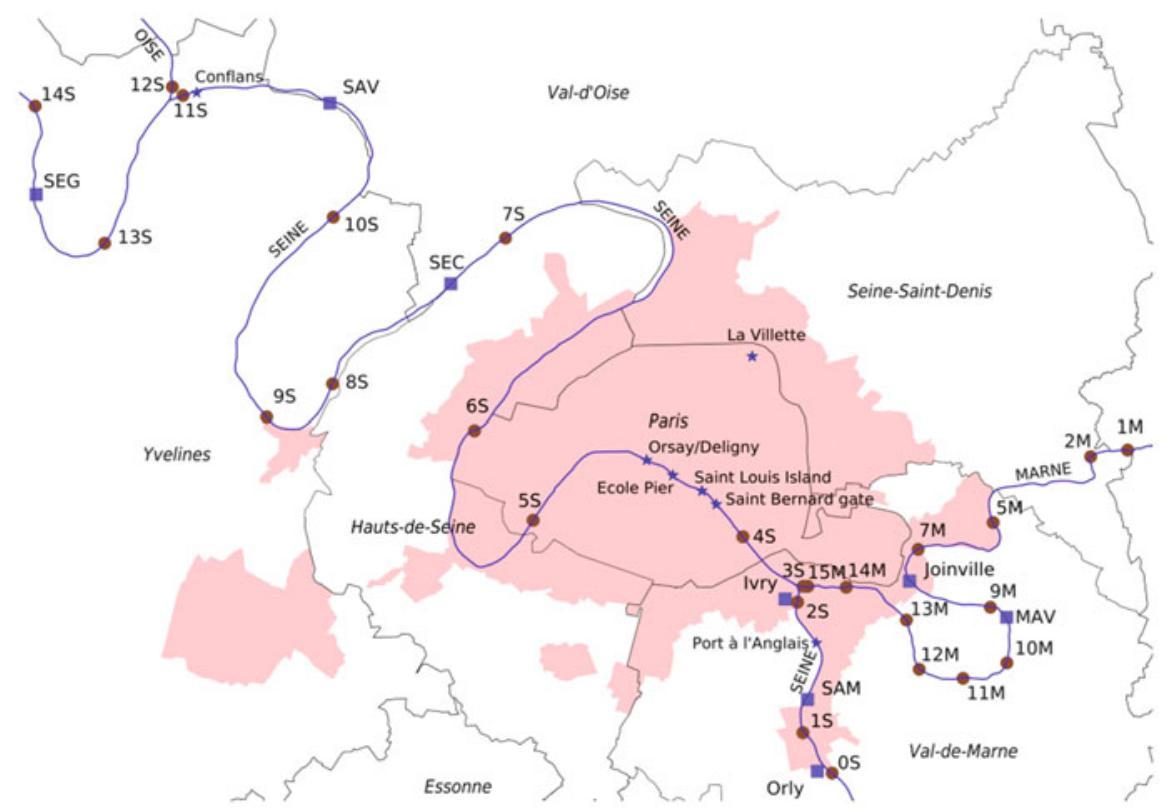

Fig. 1 Situation map. Dots indicate the stations where FIBs have been measured. Squares represent the inlet of drinking water production plants (Joinville, Orly, and Ivry) or the outlet of wastewater treatment plants (MAV, SAM, SEC, SAV, SEG). Present-day département boundaries are drawn with a dotted line; their names are in italics. The pink area represents the municipalities with a population density higher than $1,000 \mathrm{hab} / \mathrm{km}^{2}$ in 1881 . Nowadays, these municipalities would cover most of the map

microbial contaminants is the digestive tract of humans and warm-blooded animals or the aquatic environment itself. Microbial contaminants may reach the aquatic environment via wastewater treatment plant discharges, urban combined sewer overflows, sanitation system failures, agricultural and urban runoff, and direct dejection of breeding or wild animals.

In the Paris area, thanks to major improvements in wastewater treatment, the microbiological quality of water has improved significantly since the mid-1980s, and the desire to engage in swimming activities in rivers in the Paris agglomeration is spreading among the population. This objective is shared by the local authorities of Ile-de-France who wish to create or reopen bathing areas in urban rivers. Indeed, the Syndicat Marne Vive and the relevant actors of the urban Marne River have planned to open bathing areas in 2022. Similarly, the city of Paris supports a project to organize swimming events in open water in the Seine River, especially during the Olympic Games in 2024. The opportunity to bathe in urban river water motivates the development of renewed water policies in the urban area. 


\section{Bathing in the Seine and Marne Rivers in Paris and Its Suburbs Has Recently Become a Health Issue}

\subsection{Bathing in Paris: Washing and Cooling Off}

Local populations have bathed in rivers for centuries for hygienic as well as symbolic reasons; this activity has progressively evolved toward the ages at the rate of modernity, according to the social organizations and the evolution of the social norms. Beginning in the seventeenth century, bathing was a very common activity for Parisians: many of them, including the popular classes, would wash in the Seine and Marne rivers and cool off during hot periods [1]. At the Saint Bernard gate where "Men bathe at the foot [of the gate] during the heat wave; we see them throw themselves into the water, we see them come out, it's an amusement," as La Bruyère says in Les Caractères.

At the end of the eighteenth century, an increasing number of bathing boats moored on the banks of the Seine River, allowing people to take a bath in a pierced bathtub out of sight, thus avoiding social or sexual promiscuity [1]. They were run by private entrepreneurs and separation of the social classes was the rule [2]. The least expensive, so-called "quatre-sous" baths, was the most basically laid out. According to Eugène Briffault [3], the show was not very raucous: "imagine a band of demons, blackened with coal and smoke, plunging into a bath that one moment becomes thick and muddy." In this description, the chronicler's gaze attributed the poor quality of the water to its contact with individuals of another social class and not to the water itself.

The most sophisticated bathing boats offered many services such as a private cabin, hot water, a restaurant, a massage parlor, and a hairdresser. Beginning in the 1820 s, some of them developed swimming pools. All were supplied with water pumped directly in the Seine River with no filtration device. Comparing two swimming school boats, Briffault found that the water at Saint-Louis Island was "pure, clear and healthy because it has not yet crossed the Parisian cesspool" while the Orsay water was "dirty, cloudy, often foul and unhealthy because it has already rolled in the filth of the big city." But this situation was not detrimental to the reputation of the Deligny baths at Orsay, which were "opulent and majestic." The chronicler noted, however, that on days of heavy rains, the pools of Deligny became muddy and "that it is difficult to swim for a long time in these waters without having the chest soiled with a muddy deposit and ears plugged" [3]. This is a rare and early comment regarding bathing and the deterioration of water quality due to urban wet weather pollution. 


\subsection{Bathing Despite Regulations and the Development of Industry and Harbors}

The occupation of the banks and the uses of the Seine River were regulated from the beginning of the eighteenth century. A law on June 5, 1711, thus "forbids anyone to bathe in the arm of the Seine River from the bridge of the Hotel Dieu hospital, to that called the Petit Pont, the fine was 20 pounds." The same prohibition was reiterated in 1724,1737 , and 1738 [4]. It was mainly for reasons of morality that these prohibitions were imposed following the excessive behavior of some bathers exposing themselves nude close to the Hôtel Dieu Hospital. Other reasons motivated the prohibitions to bathe in the Seine River. A police order dated June 28, 1726, stated: "It is forbidden for the water carriers to draw water during the summer from the Great Degrees to the Pont Neuf and from the Saint-Paul port to the Ecole pier (...) and all people to swim in this stretch of the river, punishable by a fine of four hundred pounds." Starting from this time until the first half of the nineteenth century, on its periphery the city tended to reject all the activities likely to encumber the banks and to hinder river traffic [5]. However, wild bathing in the Seine River remained the rule for the working classes, despite the regulations and the fines, until the 1930s, which saw the development of an alternative with the municipal baths and swimming pools.

The development of shipping and the installation of warehouses and factories on the banks during the nineteenth century did not seem to change the appetite for wild bathing. In 1822, a report from the canal manager reported the presence of 150 bathers along the Bassin de la Villette, who threatened and insulted the guards [5]. In 1877, the famous sanitary engineer Durand-Claye noted that "every year since time immemorial, the Bassin de la Villette has been invaded by the crowd of workers from the neighbourhood whose number sometimes amounts to 500, 600 or even more."

\subsection{Bathing in Suburban Areas: From the Middle of the Nineteenth Century}

From the mid-nineteenth century, to escape urban and industrial life, Parisians started to enjoy the banks of the Seine and Marne rivers in the suburbs of Paris to relax or party [6]. Trams and other suburban trains facilitated access to the capital's surrounding recreational areas for the working classes as well as upper-class families, who enjoyed a picnic on the grass, a walk, a fishing party, or boating activities. The pleasure of bathing that has always been enjoyed in both rivers largely developed in these improvised spaces, appropriated by bathers, between natural cove and sandbank. Later, the Ile-de-France municipalities gradually developed the banks to create beaches and whole complexes to accommodate not only bathers but also 

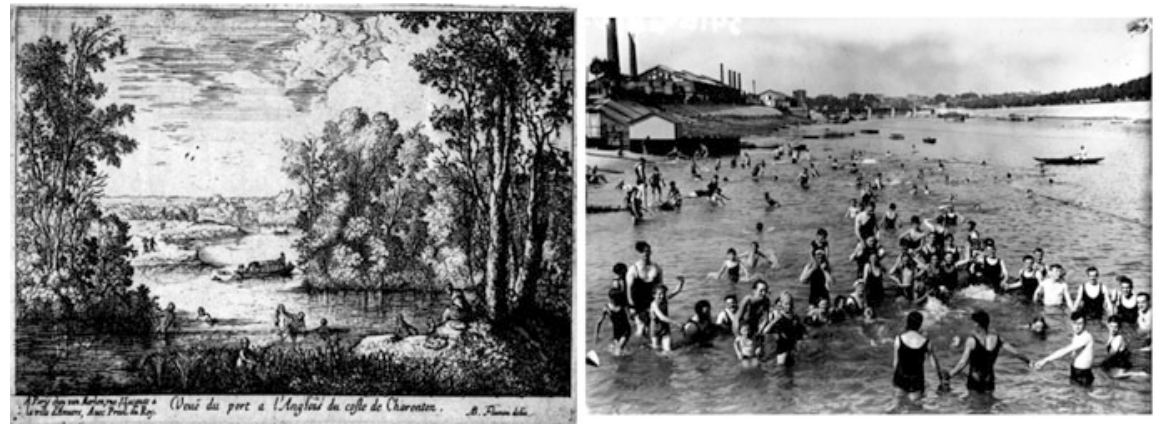

Fig. 2 Bathing at Port-à-l'Anglais. Left: Engraving by AB Flamen, about 1,650, Bibliothèque Nationale de France. Right: Bathing at Port-à-l'Anglais in 1920, gallica.bnf.fr/Agence de presse Mondial Photo-Presse

boaters and walkers often coming from the capital for a "partie de campagne" on Sundays [1].

During the second half of the nineteenth century, Joinville-le-Pont, on the Marne River, became a major spot for water sports activities. The recognition of swimming as a sport owes much to the military. The teaching of swimming in the army had to be done in the river, because of a lack of other facilities. The Joinville Gymnastics School was created in 1852; swimming took place in the Marne River from a pontoon. For 80 years instructors at the military schools were trained here and then civilians. The first swimming and diving competitions at the national and international level were organized on the banks of the Marne River at Joinville. From the beginning of the twentieth century, various establishments were multiplying along the Marne River to meet the demand for an emerging sport: swimming schools, diving boards, and landscaped pools. During the summer, thousands of Parisians and suburbanites bathed in the water of the Marne River without a second thought. These practices were banned at the end of the summer of 1970 by a prefectural decree prohibiting bathing in the Marne River because of the poor quality of the water.

In Port-à-l'Anglais, on the banks of the Seine River, upstream from Paris, bathers had been swimming in white water since the seventeenth century, as illustrated by an engraving depicting bathers in the middle of a lush natural setting (Fig. 2). Later on, after the First World War, the shorelines were gradually developed, integrating beaches and bathing places to satisfy the recreational needs of local populations, which could use a new tramway constructed in 1920 to access this area. However, the idyllic landscape of the seventeenth century was replaced from 1850 to 1950 by a forest of smoking industrial chimneys (Fig. 2), while as the nineteenth century came to an end, only rare voices were raised about the poor water quality in this area because of the discharge of raw industrial and municipal effluents into the river [7]. 
Fig. 3 Bathers and onlookers at the Iena bridge in 1945. gallica.bnf.fr/ Agence de presse Mondial Photo-Presse

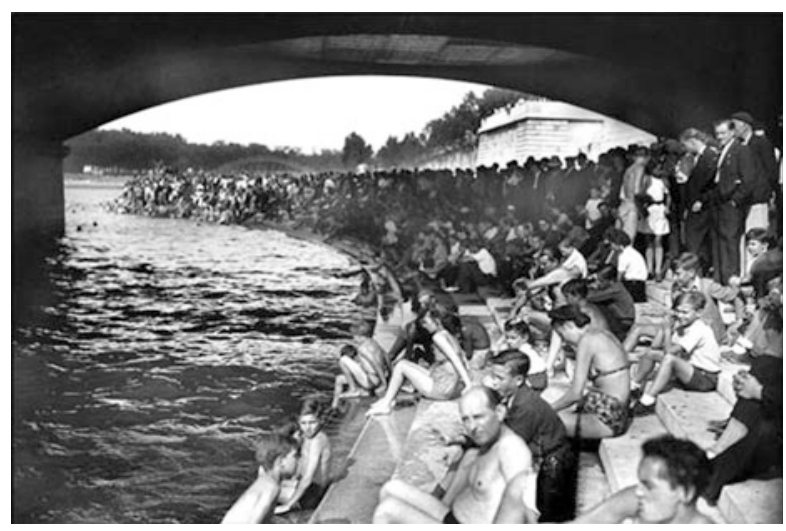

\subsection{A Social Control More Than a Matter of Public Sanitation}

The regulation of bathing in the Seine River can be divided chronologically into three periods [8]. The first corresponds to the eighteenth century: bathing is allowed in Paris but is confined to certain places chosen with the main intention of ensuring respect for morality and regulating conflicting uses of the river banks. The second period is a transitional period during which swimming became strictly forbidden in Paris in 1867, extended to the nearest suburbs in 1923, except for certain places authorized by the Police Prefecture. The last period begins in the middle of the twentieth century with repeated closures of bathing areas due to episodes of pollution. Bathing is completely prohibited in the Marne River in 1970 by prefectural decree. Finally in 2003, it was also forbidden in the Seine River within the limits of the Val-de-Marne department. Despite this legal and administrative regulation, the practice of wild bathing in the Seine and Marne rivers persisted until the end of the 1960s, a period that represents a shift in the public's perception of the health risk linked to bathing (Fig. 3).

\section{The Concept of Fecal Indicator Bacteria}

In the present EU bathing directive (2006/7/EC), the monitoring of bathing water quality is based on the concentrations of two bacterial types: Escherichia coli (EC) and intestinal enterococci (IE), which are used as fecal indicator bacteria (FIBs). The indicator concept was originally defined to evaluate the quality of drinking water and is based on several hypotheses. FIBs are residents of human and mammal intestines, they are shed in feces, and they are assumed not to grow in the soil and water environments. The presence of FIBs is assumed to be related to the presence of pathogens [9]. 
This fecal indicator paradigm developed at the end of the nineteenth century, because it was obvious that waterborne diseases were mostly gastroenteritis. Since it was impossible to monitor all enteric pathogens, microbiologists focused on FIBs as indirect predictors of their presence ([10-12]). In 1892, Schardinger [12] proposed using Bacterium coli which was isolated by Theodor Escherich in 1885 [13] and was renamed Escherichia coli in 1919 [14]. Selective media were later developed for the quantification of $E$. coli in drinking waters, surface waters, and wastewaters. Thermotolerant coliforms (also called fecal coliforms) that include E. coli were used for a while as indicators; however, their lack of specificity resulted in their being dropped in the revised Bathing Water Directive in 2006. Enterococci were integrated into the monitoring of FIBs when Slanetz et al. [15] proposed a selective medium for their detection; they were first named fecal streptococci [14].

Although the FIB concept proved to be useful for several decades to estimate potential health risk and contributed greatly to decreasing the occurrence of waterborne diseases in industrialized countries, it has many drawbacks. Some FIB strains survive and even grow in sand, sediment, soil, and waterbodies, which may serve as potential reservoirs [16-18]. Culture-based assays cannot distinguish whether the source of contamination is animal or human [19]. The correlation between coliforms and human pathogens has not been validated over a wide range of waterbodies with differences in water quality, geographic origin, climatic conditions, watershed morphology and hydrology, and local pollution inputs. In fact, the FIB/pathogen ratio in natural waters is mainly a function of the occurrence of pathogens in the population, different fates in water treatments, and different survival times in the environment. These ratios are therefore site-specific and seasonally dependent and show substantial spatial and temporal variations [20-22].

As a consequence, there is often no correlation between FIB and pathogen concentrations, which prevent efficient prediction of contamination [23-25]. In the Seine River in the Paris area, virus monitoring carried out in 2013-2014 and 2017-2018 showed no significant correlation between FIBs and a panel of various enteric viruses (Fig. 4). From January 2005 to August 2007, only a significant correlation could be found between IE and Giardia cysts in the Seine and Marne rivers [26]; other fecal bacteria were not correlated with the protozoans monitored.

To counter some of these drawbacks, new indicators were developed using molecular techniques. Microbial source tracking methods distinguish human and animal sources using genetic markers such as specific gut bacteria or comparison of bacterial communities [9, 27]. Bacteroidetes or Firmicutes species and fecal bacteriophages were identified as potential alternate indicators [19, 28]. Although somatic coliphage and F-specific RNA phage are sometimes used by stakeholders, these indicators are still not implemented in the EU Bathing Directive, and E. coli and IE remain the gold standard [29].

In conclusion, the presence of FIBs can predict the probable presence of viruses, Giardia, and Cryptosporidium in surface water affected by sewage inputs, but they cannot predict their concentration. This is in accordance with the original indicator concept in drinking water, which established FIBs as an index of fecal pollution and, therefore, the probability of the presence of pathogens and potential health risks. 

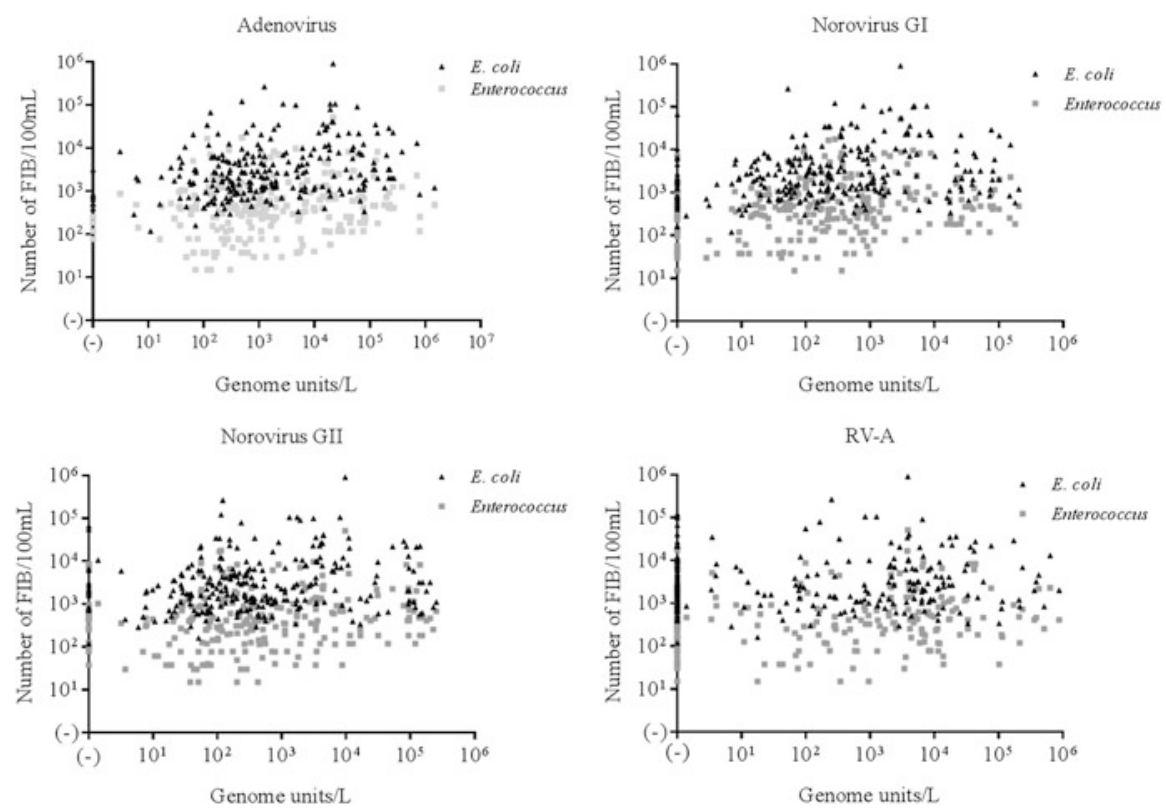

Fig. 4 Relationship between viral and FIB concentrations ( $E$. coli and IE) observed in the Seine River from two campaigns (2013-2014 and 2017-2018) $(n=257)$. (-) means not detected. $A d V$ adenovirus, $N V G I$ norovirus group I, $N V G I I$ norovirus group II, $R V$ - $A$ rotavirus A [25]

It has often been interpreted and used in a different context than its original concept, resulting in a multitude of misapplications [30].

\section{Long-Term Fluctuations of Microbiological Water Quality in the Seine and Marne Rivers}

The microbiological quality of the Seine River in the Paris area has been studied regularly since 1911. All data were collected in historical lab books from the Ville de Paris laboratory (called CRECEP data) and from the drinking water treatment plant quality laboratory (called EdP data) and carefully double-checked. SIAAP measurements were also added to the timeline. E. coli measurements were used when available (mainly in more recent years), or alternatively thermotolerant coliform measurements (called Bacterium coli, B. coli, or Th. coliforme in the lab books). All fecal coliform concentrations were transformed into $E$. coli concentrations using a ratio of 0.77 . This conversion factor was established by comparing the numbers of thermotolerant coliforms measured on plate counts and the numbers of $E$. coli enumerated using the most probable number microplate method (ISO 9308-3) in a set of samples collected in rivers in the Seine watershed [31]. This ratio is in accordance with the ratio observed $(E$. coli/thermotolerant coliforms $=0.8$, 


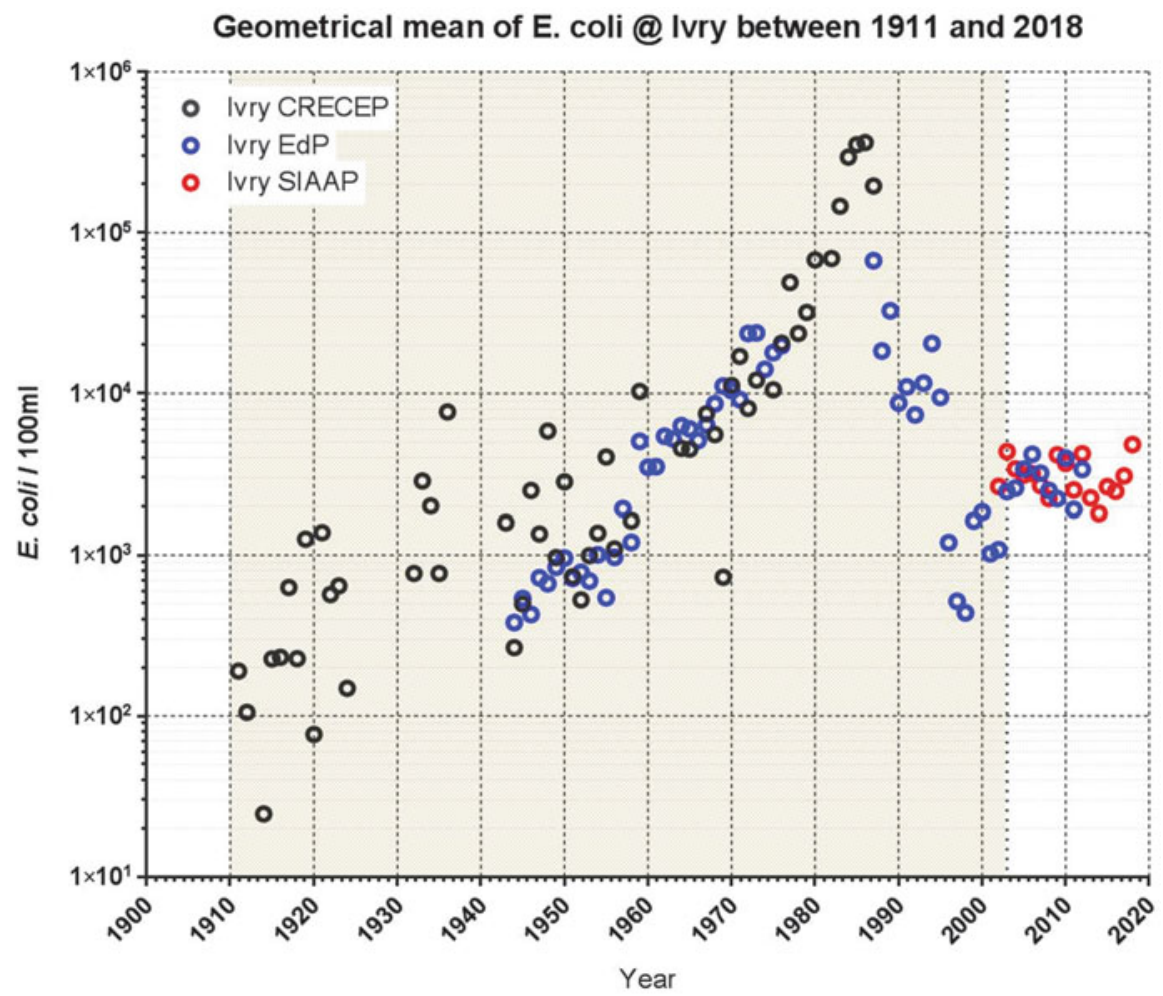

Fig. 5 Annual geometrical means of E. coli concentrations in the Seine River at Ivry between 1911 and 2018. Data were collected from the Ville de Paris laboratory (CRECEP in black open circles), the Ivry drinking water plant (EdP in blue open circles), and SIAAP (red open circles). The colored background indicates the period during which $E$. coli concentrations were estimated from the concentrations of thermotolerant coliforms converted to E. coli data using an E. coli to coliform ratio of 0.77

$n=650)$ in the historical data for the period during which both parameters were measured simultaneously. After verification of the data collected, E. coli's annual geometrical means were calculated for each year to limit any influence of highly divergent results. The number of data taken into account per year varied from 4 to 254 .

Figure 5 shows the evolution of the annual geometric mean of $E$. coli in the Seine River at Ivry just upstream from the confluence with the Marne River and from the entrance to Paris. Although caution is advised when comparing measurements made over a period of a century with methods that have evolved over time, it seems clear that there was deterioration in microbiological quality from the beginning of the century to the 1980s. For periods when two data sets are available, there is good concordance between the two annual geometric means calculated taking into account the fact that samples were not collected at the same frequency and on the same dates for both data sets; this gives us confidence in the data presented in Fig. 5. 
During the 1950 s to the 1980 s, water quality deteriorated very rapidly, and the maximum annual geometric mean of concentrations $\left(5 \times 10^{5}\right.$ E. coli/100 mL) was reached in 1985. This accelerated quality degradation is related, on the one hand, to a significant increase in the urban population upstream from Paris (the urban population quadrupled between the 1950s and the 1980s [32]) and, on the other hand, to a slow implementation of domestic sewage treatment plants. After the mid-1980s, there was a very rapid and significant improvement of the microbiological quality at the Ivry sampling site. This is partly due to the commissioning of the Seine Amont WWTP located $4 \mathrm{~km}$ upstream from Ivry. The geometric means of E. coli concentrations continued to decrease until the beginning of the 2000s (Fig. 5). This improvement was first related to the widespread installation of new WWTPs and to subsequent improvement of their treatment processes. Since 2000, the microbiological quality has been quite stable, with annual geometric means around $3-5 \times 10^{3}$ E. coli/100 mL.

The evolution of the annual geometric mean of $E$. coli in the Seine River downstream from Paris at Conflans is presented in Fig. 6. The Conflans sampling station is located just upstream from the confluence of the Seine River with the Oise River. This station is situated downstream from the outfall of the effluents of the Seine Aval (SAV) WWTP, which today treats $70 \%$ of the wastewaters from the Paris agglomeration. During the entire 1911-1980 period, the E. coli concentrations were always significantly higher in Conflans compared to the concentrations measured in Ivry. The difference between the two stations was maximum in the 1950s (with annual geometric means sometimes two log units higher in Conflans than in Ivry). Unfortunately, data are not available for the period between 1980 and 2000, which probably displayed the highest contamination levels in Conflans. In recent years (since 2000), the E. coli concentrations have continued to decrease, with geometric means between $5 \times 10^{3}$ and $10^{4}$ E. coli/100 mL. This can be attributed to the major improvements of the treatment processes in the SAV WWTP [33] and also to a reduction in the volume of effluents discharged by combined sewer overflows (CSOs) in the Seine River downstream from Paris (see the next section).

\section{Sources of Fecal Contamination}

When assessing the contamination of natural aquatic ecosystems by microorganisms of fecal origin, it is usual to distinguish point sources from nonpoint sources, also called diffuse sources. Microbial contaminants brought by surface runoff and soil leaching constitute the diffuse sources, which also include contamination linked to leakage from sanitation sewers and septic tanks and also direct defecation of certain animals (e.g., cows, waterfowl) in surface waters. The outfalls of raw urban wastewater, domestic WWTP effluents, industrial effluents, and urban runoff waters collected in separate sewer systems and CSOs constitute the point sources.

The inputs of fecal microorganisms via nonpoint sources are not easy to quantify. To assess the contribution of nonpoint sources to river fecal contamination, 


\section{Geometrical mean of E. coli @ Conflans between 1911 and 2018}

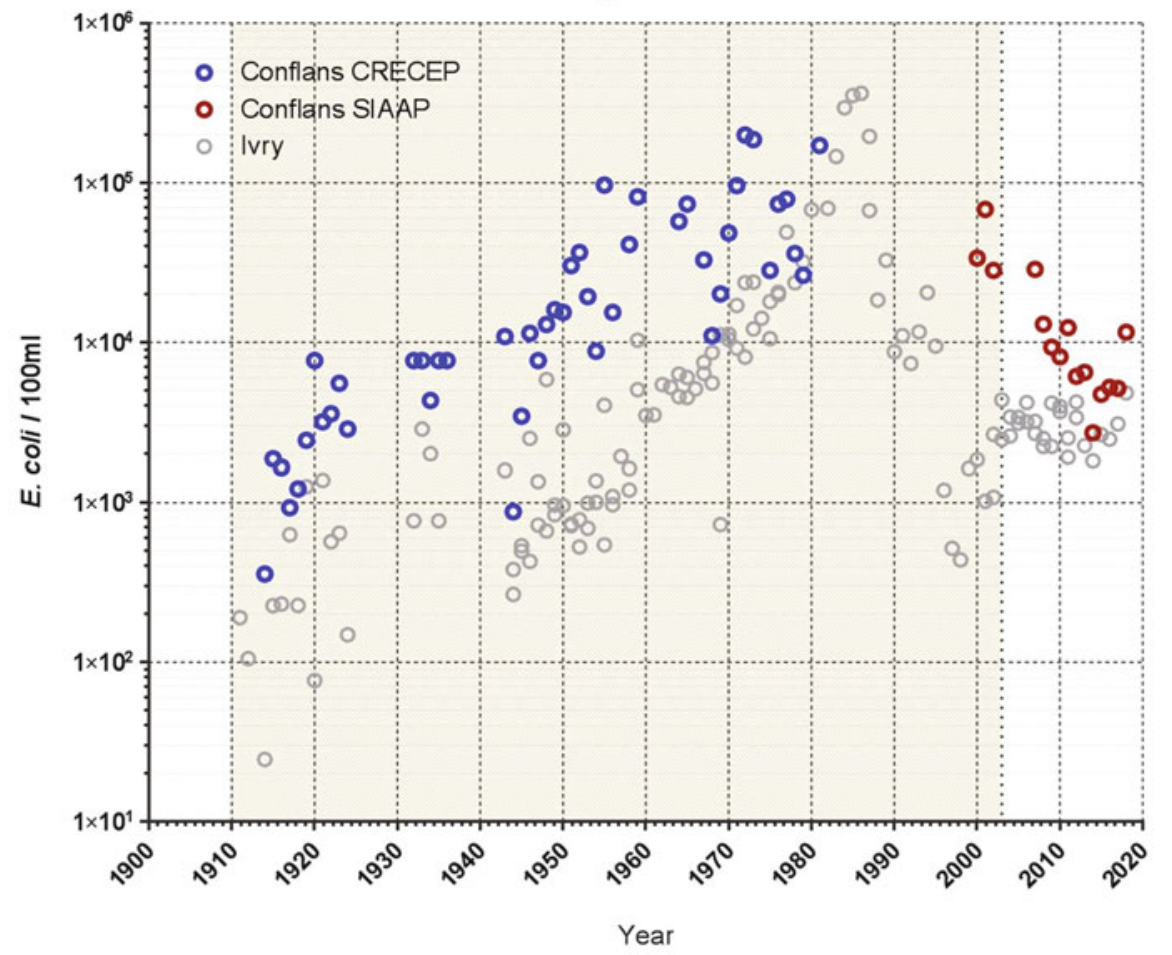

Fig. 6 Annual geometrical means of E. coli concentrations in the Seine River at Conflans (downstream from Paris) and Ivry (upstream from Paris) (light gray circles; see data from Fig. 5) between 1911 and 2018. Data at Conflans were collected from the Ville de Paris laboratory (CRECEP in blue open circles) and SIAAP (red open circles). The colored background indicates the period during which $E$. coli concentrations were estimated from the concentrations of thermotolerant coliforms and converted to $E$. coli data using an E. coli to coliform ratio of 0.77

concentrations of FIB in small streams upstream of any source of domestic contamination were measured, while these small streams were characterized on the basis of the land use of their watershed: forests and cultivated and grazed areas [34]. These data show that the concentrations measured depend greatly on the land use of the watershed [35, 36]. Small streams located in pastured areas presented contamination levels (median values of FIB concentrations: 250 E. coli/100 mL and $100 \mathrm{IE} /$ $100 \mathrm{~mL}$ ) around one order of magnitude higher than the streams located in forest or crop areas (median values of FIB concentrations: 42 E. coli/100 mL and $11 \mathrm{IE} /$ $100 \mathrm{~mL}$ ). This clearly demonstrates the importance of manure grazing livestock as a source of fecal contamination of surface waters in rural areas in the Seine River catchment.

Concentrations of microorganisms of fecal origin are very high in raw domestic wastewaters [37]. For example, Fig. 7 shows that median concentrations in raw 


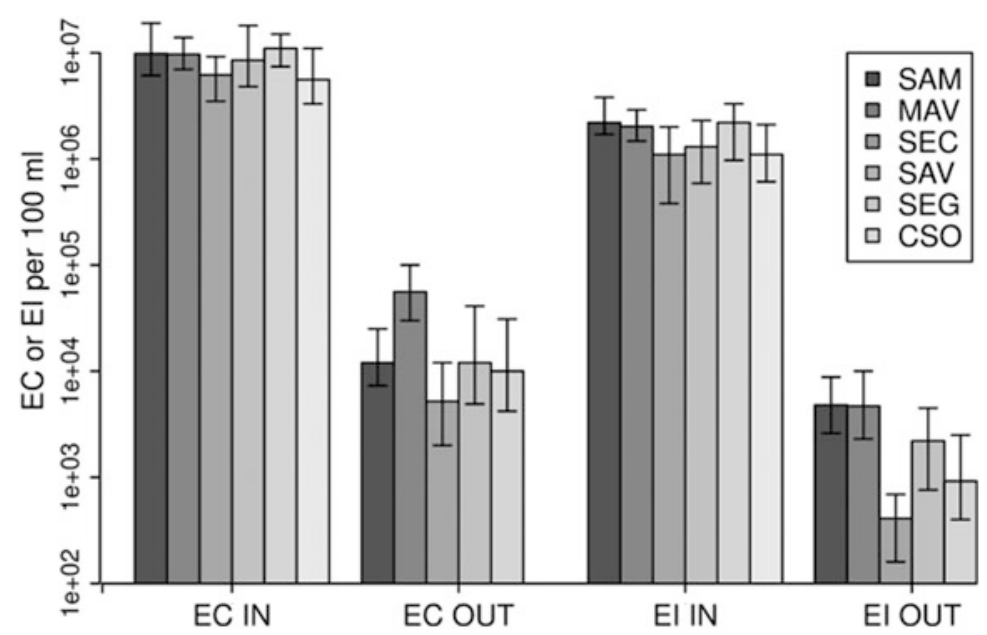

Fig. 7 E. coli (EC) and intestinal enterococci (IE), concentrations in raw (IN) and treated waters (OUT) of the five WWTPs located in the Paris area releasing their effluents in the Seine River (SAM Seine Amont, SEC Seine Centre, SAV Seine Aval, SEG Seine Grésillons, MAV Marne Aval) and in the two major combined sewer overflows (CSO, no treatment, raw water only) located at Clichy and La Briche. The gray blocks indicate the median values and the vertical black bars represent the range between the first and the third quartiles. Data from [33], data collected between 2012 and 2015, additional unpublished data for MAV IN were collected in 2010-2011

sewage entering Parisian WWTPs ranged between $6.2 \times 10^{6}$ and $1.1 \times 10^{7} / 100 \mathrm{~mL}$ for E. coli and between $1.2 \times 10^{6}$ and $2.2 \times 10^{6} / 100 \mathrm{~mL}$ for IE. WWTPs have not been specifically designed to remove fecal microorganisms but rather to remove suspended solids, organic matter (especially its biodegradable fraction), nitrogen, and phosphorus. They are quite efficient in removing FIBs, however. Studies conducted on the removal of fecal bacteria in WWTPs in the Seine watershed usually showed a 2-log-unit reduction of FIBs for plants using a primary settling treatment followed by an activated sludge process [32, 35, 38]. When a tertiary treatment is added to decrease nitrogen and phosphorus concentrations, an improvement in the removal of FIB is usually observed. In the Paris WWTPs, tertiary treatment is applied [33]: Fig. 7 shows log reductions varying between 2.9 and $3.1 \log$ units for $E$. coli and between 2.7 and 3.4 for IE. Although FIBs are efficiently removed in the Paris WWTPs, their concentrations in treated effluents are still high (median values between $5.2 \times 10^{3}$ and $1.2 \times 10^{4}$ for $E$. coli and between $4.2 \times 10^{2}$ and $4.8 \times 10^{3}$ for IE). A way to decrease the concentrations of fecal microorganisms in the treated effluents is to polish the treatment using a disinfection treatment. In Europe, UV irradiation is the predominant option for wastewater disinfection because its main advantage is the absence of release of chemical products in the environment. Today, WWTPs equipped with a disinfection treatment unit are scarce in the Seine watershed.

The input to the aquatic natural environments of pathogenic microorganisms from domestic wastewater is not restricted to discharges of WWTP effluents. In cities 
equipped with a combined sewer network, the water flow in the sewers significantly increases during rain events due to runoff waters, and the transport capacity of the sewer system can be insufficient to allow all the water flow to reach the WWTP, or the treatment capacity of the WWTP can be insufficient to treat all the water flow. In such cases, CSOs can occur, resulting in the direct release of untreated waters into surface waters. The content of pathogenic microorganisms and FIBs in CSO is slightly lower compared to raw sewage entering the WWTPs during dry weather (Fig. 7). This is due to the dilution of domestic waters by runoff waters that are less contaminated by fecal microorganisms. Studies conducted after intense rain events in the Seine River downstream of one of the major CSO outfalls in Clichy have shown that the FIBs brought by the CSO can result in FIB concentrations in the Seine River exceeding the usual dry weather concentrations by two orders of magnitude [39].

In the last few years, the SIAAP (Syndicat Interdépartemental pour l'Assainissement de l'Agglomération Parisienne, in charge of the management of the sewer network and the WWTPs in the Paris agglomeration) has made a significant attempt to reduce the frequency and the volume of the CSO released into the Seine River (e.g., by building storage tunnels and detention basins). It resulted in a significant decrease of the annual volume of CSOs in the Paris area from $80 \sim 100 \times 10^{6} \mathrm{~m}^{3}$ (volume discharged by the three main CSO outfalls located downstream from Paris at Clichy, La Briche, and La Frette) during the 2000-2002 period to around $15 \times 10^{6} \mathrm{~m}^{3}$ in 2015 [40]. With knowledge of the annual CSO volume and the annual volume treated in the Paris WWTPs $\left(800 \times 10^{6} \mathrm{~m}^{3}\right)$ and the FIB concentrations in CSOs and treated effluents (Fig. 7), the annual flux of FIBs brought to the Seine River by CSOs and WWTPs was calculated. For E. coli, an annual flux value of $1 \times 10^{17}$ for the WWTPs and $8 \times 10^{17}$ for CSOs were estimated for the very recent years. Even if these data are approximate values, they clearly demonstrate that CSOs are nowadays the major source of microbiological contamination of the Seine River in the Paris area.

\section{The EU Bathing Water Directive}

In the 1970s, the World Health Organization (WHO) stated the existence of a link between the microbiological quality of waters and the health of swimmers. Specific European regulations for the management of the water quality of bathing areas appeared in $1975(76 / 160 / \mathrm{EU})$. Based on WHO recommendations, the bathing directive provided guidelines for grading the water quality of bathing sites using FIB count data. Its main purpose was to safeguard public health against microbial pollution.

The directive was modified in 2006 (2006/7/EC) to consider recent advances in risk evaluation for bathers. In addition to previously existing epidemiological data [41, 42], a more recent epidemiological study was available for fresh water in Germany [43]. These epidemiological studies explore the most likely illnesses that 
can be attributed to contact with or ingestion of water while bathing [41]: gastrointestinal symptoms; eye infections; skin complaints; ear, nose, and throat infections; and respiratory illnesses. They are the major source of evidence, in marine and fresh water, that was used to define the criteria of the European Directive. In all studies a non-bathing population is used as a reference; surveys are conducted to characterize the bathing in great detail; the symptoms of swimmers and nonswimmers are queried about 1 week after the bathing event (up to 3 weeks for one study). Despite efforts to make the results as comparable as possible, differences may occur between studies. They may concern the criteria used to define the severity of the disease and to qualify bathing (one bath or one day at the beach, head immersed or not, duration of the bath, etc.). In a randomized study, Wiedenmann et al. [43] enrolled participants to bathe with a very precise protocol, which was not the case for other studies. Moreover, the data (number of diseases) can be given for sites with different levels of contamination or can be classified as a function of the recorded contamination level in case of a whole season survey at a single site; this is another source of discrepancy. Nevertheless, it is important to compare all these data to provide an integrated vision because epidemiological studies are rare, in particular for fresh water.

In Fig. 8, we gathered data from selected studies, conducted in fresh water (lake shores and rivers) in the USA and Europe, regarding the occurrence of highly probable gastroenteritis. E. coli or fecal coliform concentrations were selected to characterize water quality. Gastroenteritis is the most frequent disease reported among swimmers, although not the most dangerous. Figure 8 shows the variability that may exist between studies. However, above 200 E. coli per $100 \mathrm{~mL}$ (geometric mean), all studies show an excess risk of gastroenteritis, while one study showed an excess risk for concentrations as low as 10 E. coli per $100 \mathrm{~mL}$.

The European Directive (2006/7/EC) defines a set of criteria based on E. coli and intestinal enterococci concentrations to characterize the excellent, good, sufficient, and poor status of bathing water (Table 1). More stringent criteria exist for marine water. Although bathing can be authorized in water with sufficient quality, and even a poor quality under specific circumstances, the directive recommends bringing as many bathing areas in Europe as possible to a good water quality status.

Water quality monitoring is required during at least four successive bathing seasons, and the data set to estimate water quality must include more than 16 samples. Bathing in an area with a poor status can be temporarily authorized, but it will be closed after 5 years of poor status. The directive also demands "bathing water profiles" to inform the public of the characteristics of the catchment, risks, and the occurrence of short-term events that might require the temporary closure of the bathing area and measures taken to limit risks (policies regarding spreading of manure or sewage sludge, sewer system management, wastewater disinfection, etc.). The bathing water profile should also inform on all additional potential risks (cyanobacteria or algal blooms, motor water sports, etc.).

For areas with a high frequency of dangerous short-term events, the directive allows disregarding no more than $15 \%$ of the samples with the highest concentrations before the estimation of the quality criteria. This imposes setting up efficient management measures including surveillance, early warning systems, and 


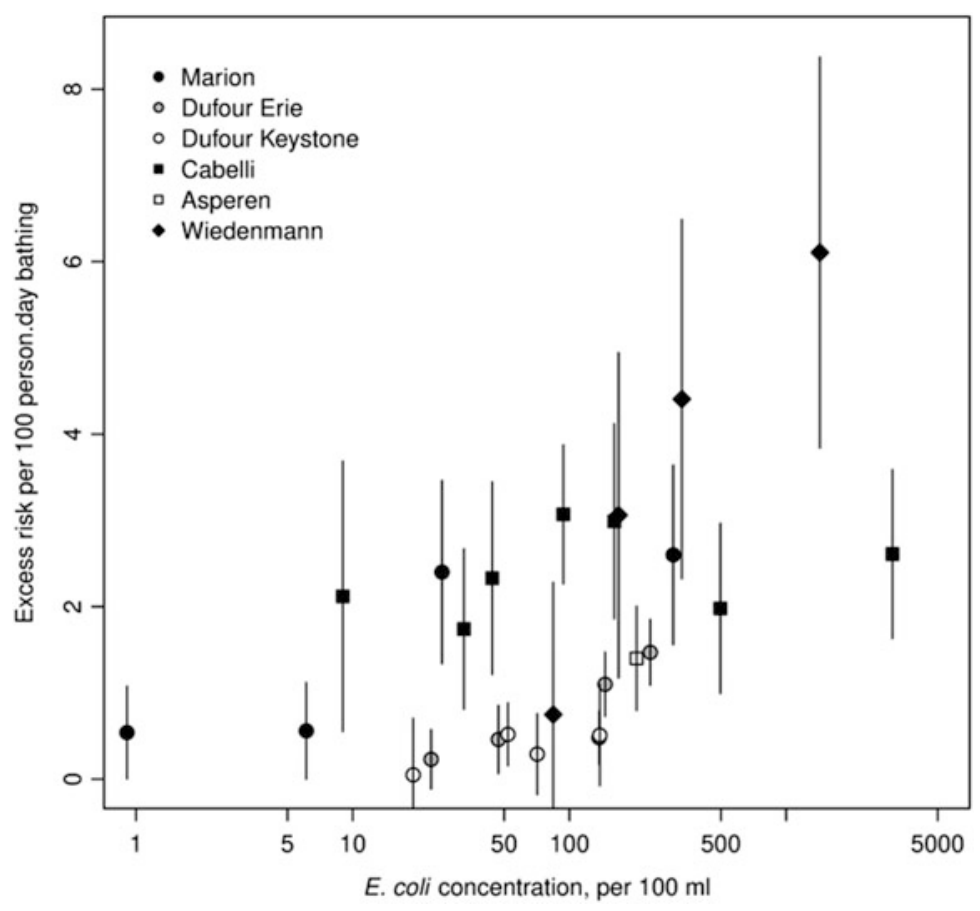

Fig. 8 Excess risk of highly credible gastrointestinal disease (HCGI), or a similar set of symptoms, from seven studies conducted from 1982 to 2010. The $x$-axis is the geometric mean of the concentration of E. coli or fecal coliforms in water. Excess risk was computed as the difference between the occurrence of HCGI in the bathing population and the non-bathing population. Data from [43-47]

Table 1 Quality criteria regarding E. coli and intestinal enterococci for inland water in the 2006/7/ EC directive

\begin{tabular}{l|l|l|l|l}
\hline & Excellent & Good & Sufficient & Poor \\
\hline E. coli & $<500^{\mathrm{a}}$ & $<1000^{\mathrm{a}}$ & $<900^{\mathrm{b}}$ & $>900^{\mathrm{b}}$ \\
\hline IE & $<200^{\mathrm{a}}$ & $<400^{\mathrm{a}}$ & $<330^{\mathrm{b}}$ & $>330^{\mathrm{b}}$ \\
\hline
\end{tabular}

According to the European Directive, the percentiles are computed assuming a log-normal distribution of the data and must be computed as the percentiles of the log-normal distribution that fits the data. 90th percentile, antilog $(\mu+1,282 \sigma)$; 95th percentile, antilog $(\mu+1.65 \sigma)$

${ }^{\mathrm{a}} 95$ th percentile

${ }^{\mathrm{b}} 90$ th percentile

monitoring, to prevent bathers' exposure by means of a warning or, where necessary, bathing prohibition.

But zero risk does not exist. The choice of water quality criteria results from a complex synthesis regarding the acceptability of risk and the existing epidemiological knowledge. Therefore, standards may differ in different countries. As stated by 
AFSSE [48], the excess risk of gastroenteritis for the sufficient criteria based on E. coli in fresh water in Europe is in the range 1.5-2.2\% per bath.

The 2006/7/EC directive should soon be reviewed. The WHO [29] made a series of recommendations to simplify quality criteria and strengthen monitoring. However, it is suggested that FIBs remain the basis for the water quality criteria since data are still lacking to develop criteria based on pathogens.

\section{Present Level of Fecal Bacteria Indicators in the Seine and Marne Rivers in the Paris Area}

Several monitoring networks provide information regarding the amount of FIB in the Marne and Seine rivers within Greater Paris: drinking water producers, municipalities, and institutions in charge of sanitation. Monitoring was recently intensified to prepare the bathing objective in 2022 in the Marne River and the organization of the Olympic Games in Paris in 2024. We selected data provided by the SIAAP, Eau de Paris, the Paris municipality, and Marne Vive to produce a comprehensive image of contamination. All data were obtained by the most probable number microplate methods for $E$. coli (ISO 9308-3) and intestinal enterococci (ISO 7899-1).

The distribution of E. coli and intestinal enterococci data in the Seine and Marne rivers shows that $85 \%$ of the samples have an EC/IE ratio higher than the ratio between the EC and IE criteria (900/330). Therefore, E. coli is a more critical parameter to define the bathing quality of both rivers, and the following sections will focus on $E$. coli.

\subsection{The Main Factors Explaining the Distribution of E. coli}

Long-term data are available at drinking water production intakes in the Seine (Orly station) and Marne (Joinville station) rivers upstream from Paris. Ten years of data covering the most recent period, and including about 1,000 data, were selected to identify the major factors impacting $E$. coli concentrations. At Orly, a regression between the log of $E$. coli concentrations and the log of the river discharge explained $33 \%$ of the $\log E$. coli concentration variance (F test $p$-value $<10^{-8}$ ). Adding the local rain of the previous day improves the explained variance up to $45 \%$ ( $p$-value $\left.<10^{-15}\right)$. The addition of rainfall of the second day before sampling did not significantly improve the regression. Highly similar results were obtained when summer data only were considered. In the Marne River at Joinville, the effect of river discharge is not significant, while the rainfall of the previous day explains $26 \%$ and $28 \%$ of the variance of $\log E$. coli concentrations ( $p$-values $<10^{-5}$ and 0.003 ).

The negative influence of rainfall events on water quality was expected since urban runoff is a known source of fecal contamination; in areas with separate sewers, 


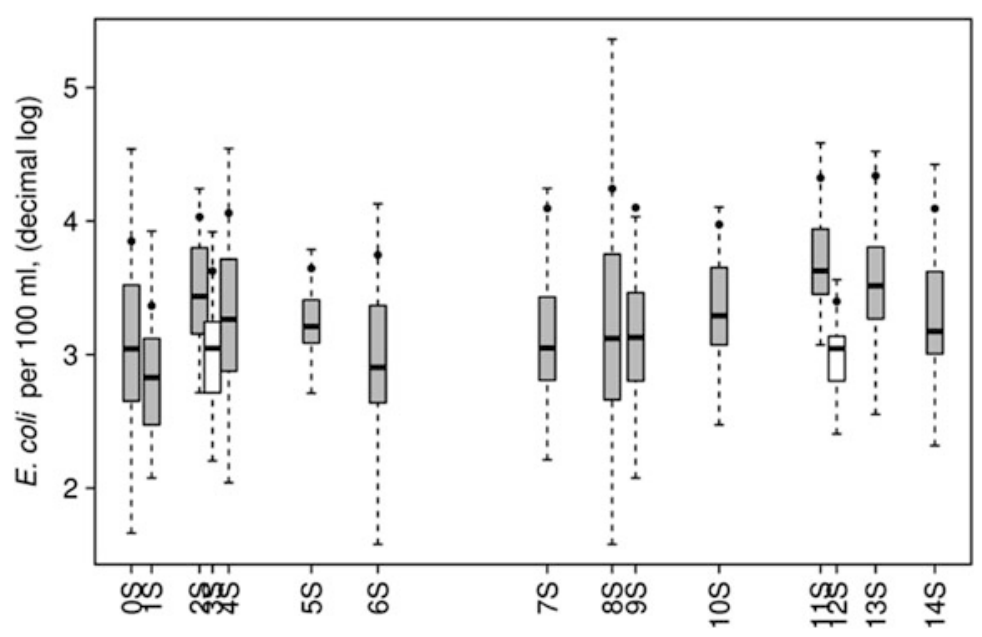

Fig. 9 E. coli concentrations during the 2014-2018 period; data were selected during the bathing season (June to September). At each station, except $0 \mathrm{~S}, 4 \mathrm{~S}$, and $5 \mathrm{~S}$, mixed samples were produced from initial samples collected close to each bank and in the center of the river flow. The central bar shows the median, the box illustrates the $25 \%$ and $75 \%$ quantiles, and the whiskers illustrate the $99 \%$ interval, assuming a log-normal distribution. Dots outside the whiskers are extreme values. The black dot is the $90 \%$ percentile. The $x$-axis is representative of the distance $(100 \mathrm{~km}$ between the most upstream and downstream stations). White boxes show the tributaries of the Seine River (Marne and Oise rivers). The number of data in each boxplot ranges from 28 to 75, except for Orly (station 0S, 335 data)

its importance is enhanced by former poor connection of housing outlets to the storm water network. An additional factor could be a decreased efficiency of WWTPs during the largest rain events [37]. The highly significant positive relationship between river discharge and the $E$. coli concentration in the Seine River likely results from a complex combination of factors. This effect is not systematically observed in all large rivers [49]. Dilution of point sources may provoke a negative correlation. The positive correlation of $E$. coli concentrations can be explained by an increased runoff and erosion in the whole river basin, notably from pastures with cattle breeding. Another very important factor is the reduced residence time of water during high-flow periods, which also reduces the extent of the degradation processes that strongly influence on E. coli concentrations.

\subsection{Longitudinal Distributions of E. coli in the Urban Sections of the Seine and Marne Rivers}

A detailed longitudinal profile along the Seine River can be drawn from the available data set. Data obtained for samples collected from June to September were selected to determine water quality during the summer bathing season (Fig. 9). Most data 
were collected bimonthly, more frequently at some stations. The 2014-2018 period was selected to limit the effect of the strong temporal trends shown in Sect. 4.

The longitudinal trends result from a combination of factors whose effect cannot all easily be separated. Inputs from wastewater discharges or tributaries can increase or dilute the E. coli concentrations, while the natural elimination processes (grazing, settling, etc.) progressively decrease the concentration. The impact of point discharges or tributaries can be compared to concentrations at the nearest downstream station, but the combined impact of diffuse sources and elimination processes between recognized inputs cannot be disentangled.

Estimates of the impact of WWTPs were computed from the median concentrations discussed in Sect. 5, from the nominal daily volumes treated by WWTPs and river discharges at the low stage (monthly average with a 2-year return period, data from the French national hydrological database). The expected concentration increases after dilution in the river were 1,080, 130, 1,810 and 1,390 E. coli per $100 \mathrm{~mL}$ for the SAM, SEC, SAV, and MAV WWTPs, respectively.

The strong increase of median concentration and flux at Ivry is twice as high as the discharge of the SAM WWTP only. This suggests the existence of additional sources. During summer 2017, contamination levels were analyzed in the Seine and Marne rivers during well-established dry weather periods [50]. Samples were taken every kilometer, near each bank, and in the center of the flow. This revealed a substantial increase of $E$. coli concentrations upstream from the Ivry station (2S), but the source was situated on the left bank, whereas the SAM WWTP is on the right bank. A combined sewer overflow, which also drains non-contaminated groundwater during dry weather, was identified as the wastewater discharging outlet. It was concluded that a malfunctioning of the sewer network in the municipalities connected to the network was probably the cause of the presence of wastewater in the CSO during a dry weather period, but the problem could not be precisely identified.

Downstream from Paris, a progressive increase of concentrations is observed, from Suresnes (6S) to Conflans (11S). More than 50\% of the concentration jump at Conflans-Seine can be attributed to the SAV WWTP, while the expected impact of the SEC WWTP is negligible. Like upstream from Paris, it is likely that much of the observed increase downstream from Paris is not only due to WWTP discharges but to malfunctions of the sewer network during dry weather, with a possible contribution of well-known major CSOs in this area and a possible delayed transport of FIBs. Dilution by the Oise River would explain most of the decrease at Poissy (13S), but the downstream decrease at Triel (14S) is mainly due to natural decay processes affecting $E$. coli in fresh water. The input of the SEG WWTP is a very minor contribution to the concentration at the Triel station.

The situation is different inside Paris and just downstream of it: E. coli concentrations tend to decrease from Tolbiac (4S) to Suresnes (6S). It is likely that better control of the sewer network has been achieved in this area, where the network is fully accessible, which may have facilitated the control of dry weather discharges.

The longitudinal profile in the Marne River (Fig. 10) is quite regular with a decrease of concentrations starting at station $5 \mathrm{M}$, which can be explained by natural 


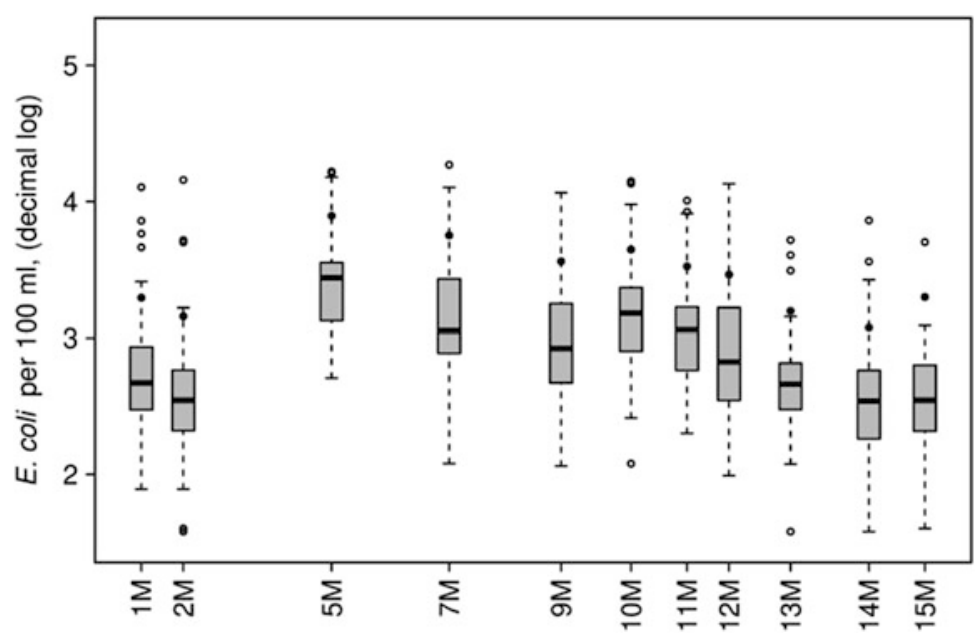

Fig. 10 Boxplot of E. coli concentrations in the Marne River during summers 2015 and 2017. The number of data in each box is within the 39-69 range. The distance between the most upstream and downstream stations is $28 \mathrm{~km}$. (see also the legend of Fig. 9)

decay processes, since the observed slope is fully coherent with the decay rates obtained from laboratory experiments. The small increase at station $10 \mathrm{M}$ downstream of the MAV WWTP can be totally explained by the estimated inputs by the outlet of the treatment plant. However, between stations 2 and $5 \mathrm{M}$, a very strong increase could be mostly explained by uncontrolled discharges during dry weather, as demonstrated by the local authority (Syndicat Marne Vive), which estimated the dry weather flux by direct measurements in a number of outlets of the sewer network in this area. As in the Seine River upstream of Ivry, erroneous connections of black water to small urban streams or storm drainage networks seem to be the major cause of the water degradation. An estimate of $2-4 \times 10^{10} \mathrm{E}$. coli per inhabitant per day can be obtained from data on the average concentration of $E$. coli in raw wastewater in the Paris suburban area and the volumes treated in the WWTPs. The concentration increase observed between stations 2 and $5 \mathrm{M}$ could be explained by the untreated wastewater flux of a few more than 2,000 inhabitants, which is negligible compared to the several million inhabitants living in the urbanized part of the Marne watershed but clearly deserves action to improve the wastewater collection system in the area concerned.

The data set analyzed above shows that the water quality inside the Paris agglomeration does not yet respect the EU Bathing Water Directive. Not to introduce too much complexity, the analysis is mainly based on so-called median fluxes computed from the median concentration and from representative low water flow in rivers. It shows that inputs of $E$. coli by WWTP discharges are important components of the overall contamination but that they would generally not explain the observed median flux increase. Uncontrolled dry weather fluxes from sewers are a major additional source. Additionally, as shown by the analysis of long-term time 
series at Orly and Joinville, the strong influence of rain events on the highest concentrations is clearly demonstrated.

\section{Presence of Pathogens in the Seine and Marne Rivers in the Paris Area}

Many waterborne diseases are not due to bacteria but to pathogenic viruses or parasites [51], as illustrated in Table 2 for the most recent period (data collected by the Centers for Disease Control and Prevention in the USA [52]). Such data sets suffer from substantial potential bias. Although foodborne outbreaks are easily identified, infection cases associated with waterborne outbreaks are brought to light with great difficulty due to different parameters: incubation time before symptom appearance, distance between contamination site and patient residence site, and also the lack of specialized medical consultation and systematic reporting when symptoms appear. Although waterborne outbreaks are probably underestimated, these statistics show the variety of potential etiological agents and require extensive information regarding additional classes of pathogens.

\subsection{Viruses}

Human enteric viruses are the leading cause of non-bacterial acute gastroenteritis worldwide [53]. Transmission occurs through the oral-fecal wayroute, either by contact contamination or by consumption of contaminated food or drinking water. Although most of the time the ingestion events lead to asymptomatic infections, the enteric viruses can also cause various symptoms such as intestinal and respiratory disorders, hepatitis, and conjunctivitis. These viruses can be associated with higher morbidity and mortality for at-risk populations such as young children, the elderly, and immunocompromised patients [54]. Human enteric viruses are characterized by their ability to infect their host through the gastrointestinal pathway. Some of them can use this gateway in the body for migrating to other organs (e.g., liver, nervous system, heart) and can be responsible for specific disorders. These viruses are then

Table 2 Percentage of waterborne diseases due to recreational activities in non-treated waterbodies reported to the CDC for the 1994-2014 period (4,640 identified cases, 1,322 unidentified)

\begin{tabular}{l|l|l|l|l}
\hline Etiologic factors & $\begin{array}{l}\text { Enteric } \\
\text { bacteria }\end{array}$ & $\begin{array}{l}\text { Enteric } \\
\text { parasites }\end{array}$ & $\begin{array}{l}\text { Enteric } \\
\text { viruses }\end{array}$ & Other \\
\hline $\begin{array}{l}\text { Number of patients as a percentage of } \\
\text { identified cases }\end{array}$ & $28.4 \%$ & $10.5 \%$ & $38.4 \%$ & $22.7 \%$ \\
\hline
\end{tabular}

Enteric bacteria were mainly Shigella (73\%), enteric parasites were mainly Cryptosporidium (64\%), and enteric viruses were mainly Norovirus (84\%). "Other" includes waterborne parasites (Schistosomes, $49 \%)$, and the non-enteric bacteria Leptospira (42\%) 
shed in feces in high quantity (up to $10^{11}$ particles per gram of stool) for a few days up to several weeks [55]. Consequently, domestic wastewaters are often highly contaminated with human enteric viruses [56, 57]. These viruses are relatively resistant to various water treatments and environmental conditions and persist in the environmental waters for long periods of time. Moreover, the viruses can infect a host at a low infectious dose, from 10 to 1,000 viral particles, independently of individual immunity and genetic susceptibility to infection [58].

Estimating the risk associated with the presence of enteric viruses in the water is not a simple task. While the microbiological quality of drinking water and recreational waters is mainly based on the presence of FIBs, as described in Sect. 3, these bacteria are generally less able to persist in water and resist water treatments at a lower level than human enteric viruses. Consequently, these bacterial indicators could not be directly used to assess the viral risk [59, 60].

The estimation of risk for human health, linked to viruses in the environment, is based on the detection of infectious viruses that infect permissive cells. However, most viruses are not easily cultivable. The detection based on virus genome amplification bypasses the cultivation limitation, but genome detection does not systematically imply health risk since partially intact genomes from noninfectious particles could be amplified. The evaluation of virus capsid integrity offers complementary information. A study conducted with samples from the Seine River in the Paris area showed that few differences were observed between the detection of total genomes and encapsidated genomes [61]. These results suggest that most viruses detected in natural waters in the Paris agglomeration have intact capsids and are therefore potentially infectious. This study also suggests that virus detection by molecular methods such as real-time PCR provides a true image of the viral danger present in surface waters.

Human enteric viruses were extensively monitored using an integrity assay in the Seine River (Paris area) for several years. The results presented in Fig. 11 showed significant contamination with the viruses the most frequently implicated in gastroenteritis in humans. In the Seine River, the median value was 10,470 genome units $(\mathrm{GU} / \mathrm{L}$ for total adenovirus and 1,026 GU/L for type $\mathrm{F}$ adenovirus. The type $\mathrm{F}$ adenovirus (serotypes 40 and 41 ) accounted for about $10 \%$ of total adenoviruses. The main virus responsible for gastroenteritis in humans (norovirus) is titrated at $216 \mathrm{GU} / \mathrm{L}$ and $146 \mathrm{UG} / \mathrm{L}$ for human norovirus GI and GII, respectively. The median concentration for type A rotavirus was 4,082 GU/L. Somatic coliphages were detected by culture with a median value of $1,350 \mathrm{PFU} / \mathrm{L}$ and F-specific RNA coliphages titrated at $460 \mathrm{GU} / \mathrm{L}$.

Similar results were obtained for the Marne River (data not shown). The median values were $39,800 \mathrm{GU} / \mathrm{L}$ and 2,200 GU/L for total and type $\mathrm{F}$ adenoviruses, respectively; $1,550 \mathrm{UG} / \mathrm{L}$ and $976 \mathrm{GU} / \mathrm{L}$ for human noroviruses GI and GII, respectively; and 7,026 GU/L for type A rotavirus. Viral indicators were titrated at $1700 \mathrm{GU} / \mathrm{L}$ and 15,262 GU/L for somatic and F-specific RNA coliphages, respectively. In both rivers, human enteroviruses (including poliovirus) were infrequently detected. 

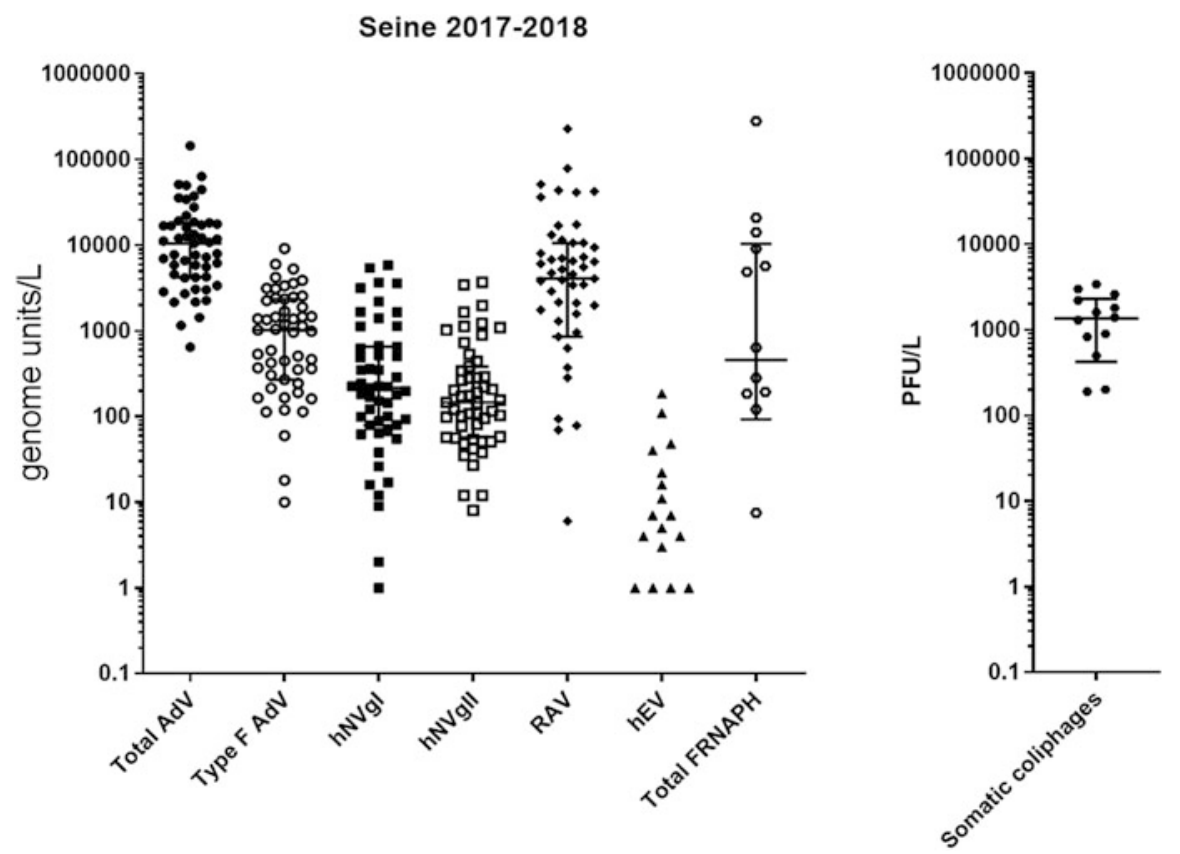

Fig. 11 Concentration of infectious human enteric viruses in the Seine River in 2017-2018. Adenovirus (AdV), type $\mathrm{F}$ adenovirus, human norovirus groups I and II ( $\mathrm{hNVgI}$ and $\mathrm{hNVgII}$ ), rotavirus (RAV), human enteroviruses (hEV), F-specific RNA (FRNAPH), and somatic coliphages. Horizontal bars show the median and interquartiles

Wastewater treatment is a crucial issue to reduce the risk of contamination, although, by design, WWTPs are generally not built to reduce viral contamination [62]. The results of intensive monitoring of viral contamination in the Seine River over 1 year [25] showed that treated wastewater from WWTPs was the main sources of pathogenic viruses. The contribution of CSOs, which could not be sampled, remains unknown. The equilibrated balance of virus flows in both sections studied suggests a very limited loss of viruses during their transit in the river (Fig. 12).

\subsection{Parasites}

Other well-known pathogens in water are the parasites, especially Cryptosporidium and Giardia. These two taxa are intestinal protozoa causing mild to severe infections in humans [63]. Cryptosporidium oocysts and Giardia cysts are often excreted in large quantities with the feces of infected animals and humans. Runoff from contaminated soils and WWTP discharges are responsible for surface water contamination [64]. Oocysts and cysts remain infective for months in environmental waters and are highly resistant to oxidative disinfectants [65]. Although the minimum quantity 

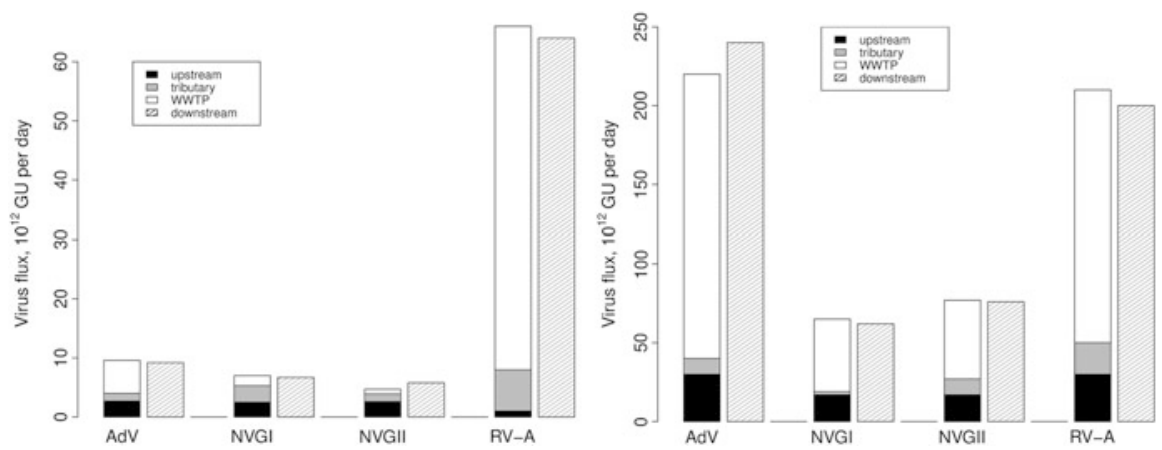

Fig. 12 Average infectious virus fluxes (GU per day) over 1 year (May 2013 to May 2014); 25 samples were collected and analyzed at each station. Left, sector A (1S-6S), right, sector B (8S13S). Data from [25]. AdV, adenovirus; NVGI and NVGII, norovirus, group I and II; RV-A, rotavirus A

of ingested cysts necessary to infect humans is often debated in the medical literature, it is well known that humans can be infected by a low level of cysts in drinking water and during recreational activities such as swimming. Since 2001, Cryptosporidium oocysts and Giardia cysts are monitored in water supplies and drinking waters using a normalized method with a concentration of $20 \mathrm{~L}$ of surface water followed by IMS concentration and microscope counting after immune staining of the concentrate (NF T90-455, AFNOR, 2014).

In the Paris area, a large monitoring project helped to describe the contamination of surface water by these parasites. Results from 2005 to 2008 [26, 64] showed that if the level of parasites is relatively low (about 1-4 Cryptosporidium oocysts/10 L and 30-50 Giardia cysts/10 L), specific events could induce significant contamination (Fig. 13). Moreover, the contamination of surface water is not totally related to WWTPs and probably more to agricultural practices upstream in the Seine catchment. Monitoring of Cryptosporidium and Giardia in the Seine and Marne rivers between 2010 and 2018 shows that the concentration of such microorganisms has been relatively stable since 2005 and follows the same pattern (see Fig. 13) with substantial variation of parasites, unrelated to the increase in fecal indicators. The small increase of the mean values between the two periods is not statistically significant.

\section{Where to Now?}

As shown in Sect. 7, most of the stations in the Marne and Seine rivers do not presently attain the $E$. coli 90 th percentile required for bathing. To illustrate the necessary effort, a simplified evaluation of two complementary strategies will be presented below. The first strategy is the reduction of the base dry weather input of $E$. coli into the river, from WWTPs and diffuse leakages off the sewer system. 


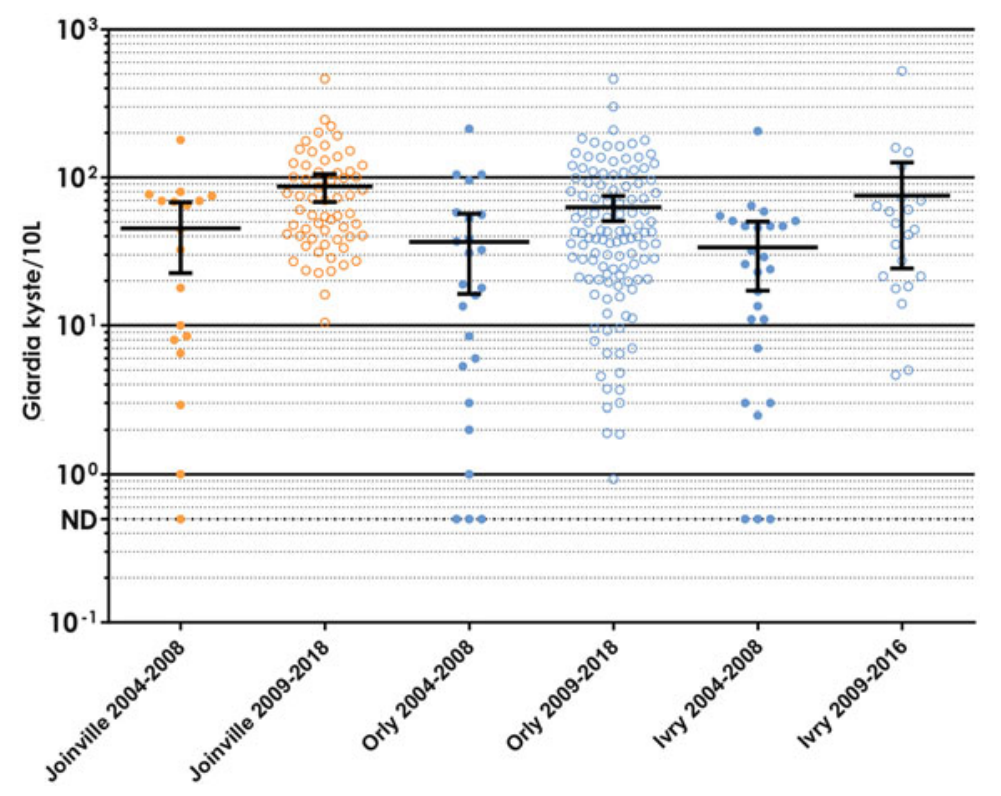

Fig. 13 Giardia concentration (in cysts/10 L) for the Marne and Seine rivers at Orly and Ivry for two sampling campaigns (2005-2008 and 2009-2018, except for Ivry 2009-2016). Mean and 95\% confidence intervals are shown in black

The second strategy is to improve the management of urban runoff by increasing infiltration or storage to reduce the impact of storm inputs into the river.

Simulation results are presented in Fig. 14 for station $7 \mathrm{M}$ in the Marne River. This station was chosen because of its symbolic value, because Joinville was one of major bathing places in the Marne River at the beginning of the century, and because its contamination level is representative of that of the whole area: $60 \%$ of all stations studied in the Seine and Marne rivers have E. coli 90 th percentiles lower than the $7 \mathrm{M}$ station.

We hypothesize that the concentrations lower than the median value are mostly representative of dry weather conditions and that the upper concentrations are additionally influenced by wet weather inputs. The reduction of the dry weather flux is simulated by a reduction factor globally simulating the efficiency of disinfection in WWTPs and of the necessary elimination of black water connections to the urban runoff network. The improved urban runoff management is simulated by additional storage or infiltration capacity expressed as a fraction of the maximum wet weather additional impact.

Two situations were tested, with and without the existence of a reliable bathing management plan making it possible to remove the $15 \%$ most degrading events to compute the statistics, following the European Directive. These results show that for a rather contaminated station, the required contamination level for bathing can be reached for a reduction of $80 \%$ of the dry weather inputs and increased storage or 
a

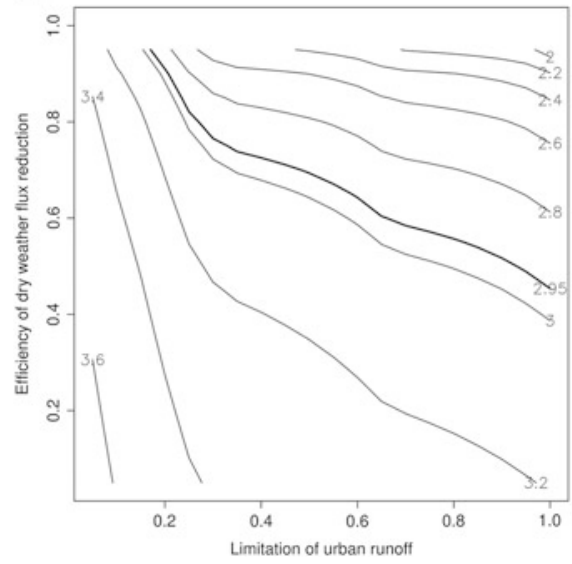

b

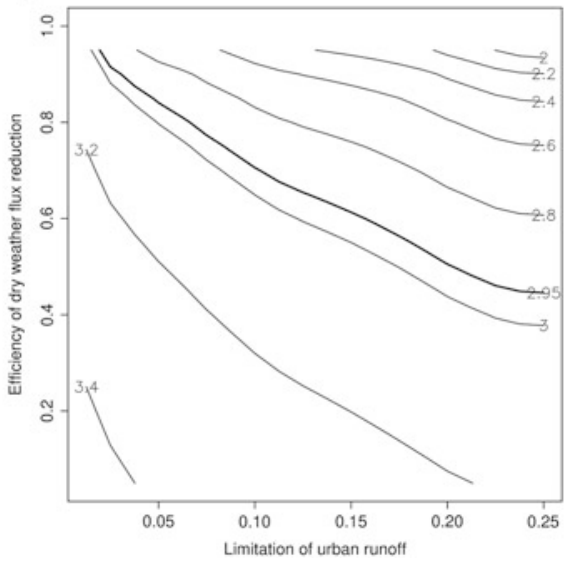

Fig. 14 Illustration of the efficiency of two policy lines to improve water quality at station $7 \mathrm{M}$. Isocurves are the 90th percentiles of $E$. coli concentrations on a decimal log scale. The sufficient criterion ( 900 E. coli per $100 \mathrm{~mL}$ ) means a log value of 2.95 (bold line). Left, simulation (a), all data; right, simulation (b) $15 \%$ of the most degrading events removed. The $x$-axis represents a reduction of the runoff volume expressed as a fraction of the most degrading recorded event, 1 means the elimination of all rain events. The $y$-axis represents the reduction of dry weather inputs (all included) a fraction of the present situation, 1 means 100\% reduction. Note the modified scale on the $x$-axis on the figure on the right

infiltration capacity equivalent to $7-8 \%$ of the volume of the most contaminating event to reduce runoff (Fig. 14, simulation (b)). Such a dry weather input reduction seems feasible regarding the potential improvement of treatments in WWTPs (see below) but requires careful improvements of bad connections in sewer networks for stations, such as station $7 \mathrm{M}$, where this additional source of dry weather contamination is much significant. With a policy regarding runoff focusing on the disconnection of black water inputs to urban runoff, efficacy as high as $60 \%$ would be required to reach the same objective (scenario not shown on Fig. 14).

To reduce the base dry weather input to the rivers, the addition of disinfection to the WWTP is an option being examined. Two techniques have been tested at full scale and have succeeded in very significantly inactivating discharged bacteria. It is now mostly a matter of political will requiring a decision on whether the construction and maintenance costs are worth the expected improvement in the river's water quality.

A full-scale UV treatment was installed in one of the WWTPs with irradiation rates about $50 \mathrm{~mJ} / \mathrm{cm}^{2}$. This reduced E. coli and IE by 1.7 and $1.3 \log$ units, respectively [33]. However, the removal efficiency of the process varied significantly over time in relation to the suspended solids (from 4 to $180 \mathrm{mg} / \mathrm{L}$ in this study) contained in the treated wastewater; it was greatly improved (2.6 and $2.1 \log$ units for $E$. coli and IE, respectively) for situations below $10 \mathrm{mg} / \mathrm{L}$. 
The addition of chemical disinfectants is another option to consider. More recently, full-size experiments were conducted in one of the Paris WWTPs by adding performic acid. Performic acid degrades very rapidly, producing free radicals that inactivate microorganisms. Reduction rates up to 2.5 and $2.7 \log$ units have been obtained for $E$. coli and IE, respectively, with a concentration at the outlet much lower than 100 bacteria per $100 \mathrm{~mL}$ for each of the FIBs (unpublished data). Endocrine disruption tests on amphibian and fish larvae (up to 4 days exposure) did not show any significant additional impact of the chemically oxidized water. These encouraging results, for chemical and UV disinfection, must be confirmed by an analysis of their potential for degradation of viruses and other pathogens given that many of them require a more stringent treatment for the same efficacy.

A second source of fecal contamination to rivers is poor connection to sewers. This most important issue will both affect base dry weather contamination fluxes and contribute to the contamination brought by rain events. Solving this problem requires a very detailed, time-consuming, and complex project to check all connections, starting from the most impacting catchments and organizing the proper reconnection of identified the buildings identified, which is under the responsibility of private individuals. It is certainly a highly delicate challenge for the recovery of a sufficient microbial water quality in the Marne and Seine rivers. Meanwhile, a complementary effort is needed to reduce urban runoff by infiltration or storage of rain water.

\section{Conclusion}

The water quality of the rivers that cross urban spaces is a concern for all [66]. Affected in their quality of life and their need for "nature," Parisians and the Ile-de-France region's inhabitants wish to reclaim the river to satisfy their needs and participate in new leisure and sports activities. The idea of a "swimmable city" was born in 2015 [67] with considerable interest on the part of local actors along the Marne River. In Paris and in its region, it became a strong political issue for the mayor of Paris and in the perspective of the 2024 Olympic Games. The expected activities also involve mobilization of all users of the Seine and Marne rivers (e.g., boatmen, industrialists, sports associations) to better preserve the quality of water and avoid conflicts of use.

This approach is part of a geopolitical context (competition between major cities regarding the attractiveness of the living environment and the development of the sustainable city) and local politics (institutional power related to the reorganization of the area, economic development, etc.). Meeting the demand of the population in their desire to win back the Seine and Marne rivers without compromising their health is one of the mobilizing issues of all the actors involved, from scientists to managers, as well as users and decision-makers, all responsible for the quality of the Seine and Marne rivers and their usage. 
Acknowledgments The authors thank Paris STEA and the Syndicat Marne Vive who provided a substantial amount of the FIB data used in this study. This research was conducted within the framework of the PIREN-Seine program, a component of the LTSER "Zone Atelier Seine."

\section{References}

1. Duhau I (2011) Les baignades en rivière en Ile-de-France. 22èmes journées scientifiques de l'environnement (Créteil, 2011)

2. Lombardo D (2011) Se baigner ensemble. Les corps au quotidien et les bains publics parisiens avant 1850 selon Daumier. Histoire Urbaine 31:47-68

3. Briffault E (1844) Paris dans l'eau, illustrated by Bertall. Initial publication by J. Hetzel. Re-edited, Bibliothèque Nationale de France, Collection XIX

4. Pardailhé-Galabrun A (1983) Les déplacements des Parisiens dans la ville aux XVIIème et XVIIIème siècles. Un essai de problématique. Histoire, Économie et Société 2:205-253

5. Backouche I (2010) Mesurer le changement urbain à la périphérie parisienne. Histoire \& mesure XXV-1 I On line. http://histoiremesure.revues.org/3929

6. Csergo J (2004) Parties de campagne. Loisirs périurbains et représentations de la banlieue parisienne, fin XVIIIe-XIXe siècles. Sociétés Représentations 17:15-50

7. Colin L (1885) Paris, sa topographie, son hygiène, ses maladies. Masson, Paris

8. Teysseire R, Corbière R, Arnac A (2013) Histoire de la baignade en Seine: les modalités de sa réglementation, Mémoire. AgroParisTech, Paris

9. Harwood VJ, Staley C, Badgley BD et al (2014) Microbial source tracking markers for detection of fecal contamination in environmental waters: relationships between pathogens and human health outcomes. FEMS Microbiol Rev 38:1-40

10. Horrocks WH (1901) An introduction to the bacteriological examination of water. Kessinger Publishing, London, p 346

11. Prescott SC, Winslow CEA (1904) Elements of bacteriology with special reference to sanitary water analysis. Kessinger Publishing, London, p 272

12. Schardinger F (1982) Uber das Vorkommen Gahrung erregender Spaltpilze im Trinkwasser und ihre Bedeutung fur die hygienische Beurtheilung desselben. Wien Klin Wochenschr 5:403-405

13. Escherich T (1885) Die Darmbakterien des Neugeborenen und Säuglings. Fortschr Med 3 (47-54):515-522

14. Edberg SC, Rice EW, Karlin RJ et al (2000) Escherichia coli: the best biological drinking water indicator for public health protection. Symp Ser Soc Appl Microbiol 29:106S-116S

15. Slanetz LW, Bent DF, Bartley CH (1955) Use of the membrane filter technique to enumerate enterococci. Public Health Rep 70:67

16. Hazen TC, Toranzos GA (1990) Tropical source water. In: McFeters GA (ed) Drinking water microbiology. Springer, New York, pp 32-52

17. Jamieson RC, Gordon RJ, Sharples KE et al (2002) Movement and persistence of fecal bacteria in agricultural soils and subsurface drainage water: a review. Can Biosyst Eng 44:1.1-1.9

18. Whitman RL, Nevers MB (2003) Foreshore sand as a source of Escherichia coli in nearshore water of a Lake Michigan Beach. Appl Environ Microbiol 69:5555-5562

19. Griffin DW, Lipp EK, McLaughlin MR et al (2001) Marine recreation and public health microbiology: quest for the ideal indicator. Bioscience 51:817-825

20. Hurst CJ, Crawford RL, Garland JL et al (2007) Manual of environmental microbiology. ASM Press, Washington, DC, p 1293

21. Dechesne M, Soyeux E (2007) Assessment of source water pathogen contamination. J Water Health 5:39-50 
22. Wilkes G, Edge T, Gannon V et al (2009) Seasonal relationships among indicator bacteria, pathogenic bacteria, Cryptosporidium oocysts, Giardia cysts, and hydrological indices for surface waters within an agricultural landscape. Water Res 43:2209-2223

23. Lund V (1996) Evaluation of E. coli as an indicator for the presence of Campylobacter jejuni and Yersinia enterocolitica in chlorinated and untreated oligotrophic lake water. Water Res 30:1528-1534

24. Bonadonna L, Briancesco R, Ottaviani M et al (2002) Occurrence of Cryptosporidium oocysts in sewage effluents and correlation with microbial, chemical and physical water variables. Environ Monit Assess 75:241-252

25. Prévost B, Lucas FS, Goncalves A et al (2015) Large scale survey of enteric viruses in river and waste water underlines the health status of the local population. Environ Int 79:42-50

26. Mons C, Dumètre A, Gosselin S et al (2009) Monitoring of Cryptosporidium and Giardia river contamination in Paris area. Water Res 43(1):211-217

27. Unno T, Staley C, Brown CM et al (2018) Fecal pollution: new trends and challenges in microbial source tracking using next-generation sequencing. Environ Microbiol 20 (9):3132-3140

28. Barrios ME, Blanco Fernández MD, Cammarata RV et al (2018) Viral tools for detection of fecal contamination and microbial source tracking in wastewater from food industries and domestic sewage. J Virol Methods 262:79-88

29. WHO (2018) WHO recommendations on scientific, analytical and epidemiological developments relevant to the parameters for bathing water quality in the Bathing Water Directive (2006/ 7/EC). World Health Organization, Geneva, p 96

30. Payment P, Locas A (2011) Pathogens in water: value and limits of correlation with microbial indicators. Ground Water 49:4-11

31. Garcia-Armisen T, Prats J, Servais P (2007) Comparison of culturable fecal coliforms and Escherichia coli enumeration in freshwaters. Can J Microbiol 53(6):798-801

32. Servais P, Billen G, Goncalvez A et al (2007) Modelling microbiological water quality in the Seine river drainage network: past, present and future situations. Hydrol Earth Syst Sci 11:1581-1592

33. Rocher V, Azimi S, Bernier J et al (2017) Qualité bactériologique des eaux en agglomération parisienne. Des eaux usées aux eaux de Seine. Edition Johanet, Paris, p 94

34. George I, Anzil A, Servais P (2004) Quantification of fecal coliforms inputs to aquatic systems through soil leaching. Water Res 38:611-618

35. Servais P, Garcia-Armisen T, George I et al (2007) Fecal bacteria in the rivers of the Seine drainage network: source, fate and modeling. Sci Total Environ 375:152-167

36. Garcia-Armisen T, Servais P (2007) Respective contributions of point and non-point sources of E. coli and enterococci in a large urbanized watershed (the Seine River, France). J Environ Manag 82(4):512-518

37. Lucas F, Thérial C, Goncalves A et al (2014) Variation of raw wastewater microbiological quality in dry and wet weather conditions. Environ Sci Pollut R 21:5318-5328

38. George I, Crop P, Servais P (2002) Fecal coliforms removal in wastewater treatment plants studied by plate counts and enzymatic methods. Water Res 36:2607-2617

39. Passerat J, Ouattara K, Mouchel JM et al (2011) Impact of an intense combined sewer overflow event on the microbiological water quality of the Seine River. Water Res 45:893-903

40. Rocher V, Azimi S, Paffoni C et al (2018) Evolution de la qualité de la Seine en lien avec les progrès de l'assainissement de 1970 à 2015. Edition Johanet, Paris, p 76

41. Prüss A (1998) Review of epidemiological studies on health effects from exposure to recreational water. Int J Epidemiol 27:1-9

42. Pena L, Zmirou D, Le Tertre A et al (2001) Critères microbiologiques de qualité des eaux de baignade. Institut de Veille Sanitaire, Saint Maurice, p 39 
43. Wiedenmann A, Krüger P, Dietz K et al (2006) A randomized controlled trial assessing infectious disease risks from bathing in fresh recreational waters in relation to the concentration of Escherichia coli, intestinal enterococci, Clostridium perfringens, and somatic coliphages. Environ Health Perspect 114:228-236

44. Marion JW, Lee J, Lemeshow S et al (2010) Association of gastrointestinal illness and recreational water exposure at an inland U.S. beach. Water Res 44:4796-4804. https://doi. org/10.1016/j.watres.2010.07.065

45. Dufour AP (1984) Health effects criteria for fresh recreational waters. US Environmental Protection Agency, Cincinnati, p 42

46. Cabelli VJ, Dufour AP, McCabe LJ et al (1982) Swimming-associated gastroenteritis and water quality. Am J Epidemiol 115:606-616

47. van Asperen IA, Medema G, Borgdorff MW et al (1998) Risk of gastroenteritis among triathletes in relation to faecal pollution of fresh waters. Int J Epidemiol 27:309-315

48. Duboudin C (2004) Qualité microbiologique des eaux de baignade. Analyse statistique des niveaux de risque et des seuils proposés par le projet de révision de la directive 76/160/CEE. Agence Française de Sécurité Sanitaire et Environnementale, Paris, p 114

49. Vermeulen LC, Hofstra N (2014) Influence of climate variables on the concentration of Escherichia coli in the Rhine, Meuse, and Drentse Aa during 1985-2010. Reg Environ Chang 14:307-319. https://doi.org/10.1007/s10113-013-0492-9

50. Mouchel JM, Colina-Moreno I, Kasmi N (2018) Évaluation des teneurs en bactéries indicatrices fécales en Seine dans l'agglomération parisienne par temps sec. Report for the City of Paris and the Water Agency Seine-Normandy, p 79

51. Craun GF, Calderon RL, Craun MF (2003) Waterborne outbreaks in the United States, 1971-2000. In: Pontius FW (ed) Drinking water regulation and health. Wiley, Hoboken, pp 45-69

52. https://www.cdc.gov/healthywater/surveillance/rec-water-surveillance-reports.html and references herein

53. Enserink R, Lugner A, Suijkerbuijk A et al (2014) Gastrointestinal and respiratory illness in children that do and do not attend child day care centers: a cost-of-illness study. PLoS One 9(8): e104940

54. Gerba CP, Rose JB, Haas CN (1996) Sensitive populations: who is at the greatest risk? Int J Food Microbiol 30(1-2):113-123

55. Blacklow N, Greenberg H (1991) Medical progress - Viral gastroenteritis. N Engl J Med 325:252-264

56. Cantalupo PG, Calgua B, Zhao G et al (2011) Raw sewage harbors diverse viral populations. mBio 2(5):e00180-e00111

57. Lodder WJ, Rutjes SA, Takumi K et al (2013) Aichi virus in sewage and surface water, the Netherlands. Emerg Infect Dis 19(8):1222-1230

58. Kirby AE, Teunis PF, Moe CL (2011) Two human challenge studies confirm high infectivity of Norwalk virus. J Infect Dis 211(1):166-167

59. Contreras-Coll N, Lucena F, Mooijman K et al (2002) Occurrence and levels of indicator bacteriophages in bathing waters throughout Europe. Water Res 36(20):4963-4974

60. Tree JA, Adams MR, Lees DN (2003) Chlorination of indicator bacteria and viruses in primary sewage effluent. Appl Environ Microbiol 69(4):2038-2043

61. Prevost B, Goulet M, Lucas FS et al (2016) Viral persistence in surface and drinking water: suitability of PCR pre-treatment with intercalating dyes. Water Res 91:68-76

62. Kitajima M, Haramoto E, Phanuwan C et al (2012) Molecular detection and genotyping of human noroviruses in influent and effluent water at a wastewater treatment plant in Japan. J Appl Microbiol 112(3):605-613

63. Fayer R (2004) Cryptosporidium: a water-borne zoonotic parasite. Vet Parasitol 126 $(1-2): 37-56$ 
64. Moulin L, Richard F, Stefania S et al (2010) Contribution of treated wastewater to the microbiological quality of Seine River in Paris. Water Res 44:5222-5231

65. Betancourt WQ, Rose JB (2004) Drinking water treatment processes for removal of Cryptosporidium and Giardia. Vet Parasitol 126:219-234

66. Euzen A, Haghe JP (2012) What kind of water is good enough to drink? The evolution of perceptions about drinking water in Paris from the seventeenth to twentieth century. Water History 4(3):231-244

67. Haghe JP, Euzen A (2018) Une nouvelle catégorisation politique des eaux: la baignade en eau libre. L'exemple de Paris. IS River, 4 juin 2018, Lyon

Open Access This chapter is licensed under the terms of the Creative Commons Attribution 4.0 International License (http://creativecommons.org/licenses/by/4.0/), which permits use, sharing, adaptation, distribution and reproduction in any medium or format, as long as you give appropriate credit to the original author(s) and the source, provide a link to the Creative Commons licence and indicate if changes were made.

The images or other third party material in this chapter are included in the chapter's Creative Commons licence, unless indicated otherwise in a credit line to the material. If material is not included in the chapter's Creative Commons licence and your intended use is not permitted by statutory regulation or exceeds the permitted use, you will need to obtain permission directly from the copyright holder. 